\title{
FROM TAREKAT TO ARAB COMMUNITY: THE ISLAMIZATION PROCESS IN INDRAMAYU
}

\author{
Roni Tabroni ${ }^{1}$, Mumuh Muhsin Z. ${ }^{2}$, Reiza D. Dienaputra ${ }^{2}$, R.M. Mulyadi ${ }^{2}$ \\ ${ }^{1)}$ Doctoral Program Student, Faculty of Cultural Sciences, Padjadjaran University \\ ${ }^{2)}$ Department of History and Philology, Faculty of Cultural Sciences, Padjadjaran \\ University
}

\begin{abstract}
This research talks about the process of Islamization in Indramayu. The Islamization in Indramayu raises three main questions. The first question is, where was the arrival of Islam in Indramayu. Second, when is the appearance of Islam. Third, who has a role in the Islamization process. This research uses the historical method, which consists of four stages: heuristic, criticism, interpretation, and historiography. This method was then collaborated with Islamic social movement theory to analyze the ideology of leadership and movement mobility of the propagator group of Islam in Indramayu. The results showed that the arrival of Islam in Indramayu came from the port of Cimanuk. Then spread to various areas, including in the countryside. Second, Islam has been dating in Indramayu since the 15th century. Third, some communities play a role in Islamization in Indramayu. The communities were very influential until the 19th century. They consisted of the Arab community and the adherents of the tarekat, especially from Cirebon. The first order to develop was Syattariyah. Meanwhile, the Arabic community leader from Cirebon was Sayyid Abdur Rahman bin Muhammad Basy-Syaiban. He is a figure who originated from the Hadramaut in the early seventeenth century.
\end{abstract}

Keywords: Tarekat Movement, Arab Community, Islamization, Indramayu

\begin{abstract}
ABSTRAK
Penelitian ini berbicara tentang proses islamisasi di Indramayu. Proses islamisasi di Indramayu memunculkan tiga pertanyaan utama. Pertanyan pertama adalah dari mama dan di mana kedatangan islam. Kedua, kapan waktu kedatangan Islam. Ketiga, siapa yang berperan dalam proses islamisasi. Untuk menjawab pertanyaan tersebut, penelitian ini menggunakan metode sejarah yang terdiri atas empat tahap: heuristic, kritik, interpretasi, dan historiografi. Pada metode ini, peneliti menggunakan teori gerakan sosial untuk melihat ideologi kepemimpinan dan Gerakan islam di Indramayu. Hasil penelitian menunjukkan bahwa kedatangan Islam di Indramayu berasal dari pelabuhan Cimanuk. Kemudian menyebar ke berbagai daerah, termasuk di pedesaan. Kedua, Islam telah dating di Indramayu sejak abad ke 15. Ketiga, terdapat komunitas yang berperan dalam Islamisasi di Indramayu. Komunitas tersebut sangat berpengaruh sampai abad ke 19. Mereka terdiri atas komunitas Arab dan para penganut tarekat, terutama dari Cirebon. Tarekat pertama yang berkembang adalah Syattariyah. Sementara itu, tokoh komunitas arab yang berasal dari Cirebon adalah Sayyid Abdur Rahman bin Muhammad Basy-Syaiban. Ia merupakan tokoh yang berasal dari Hadramaut pada awal abad ketujuh belas.
\end{abstract}

Kata kunci: Gerakan Tarekat, Komunitas Ar$\mathrm{ab}$, Islamisasi, Indramayu 


\section{INTRODUCTION}

There are three main problems related to and interrelated with the arrival of Islam in Indonesia. First, get at the place of origin of the advent of Islam. Second, who are the bearers? Third, whenever the time of his arrival. This third question then raises various opinions that cross each other, strengthen each other, and negate each other. As time went on, ideas which later gained reinforcement, weakness and eventually became approved by the facts.

There are several opinions to answer the third question above, and one of them can be referenced from the idea of Dutch scientists. The first scientist was J. Pijnappel, an academic at Leiden University who was famous for the Gujarat theory. According to Pijnappel (Drewes, 1968, pp. 439-440) the origin of Islam in the Archipelago is Gujarat (southwest India) and Malabar (south India). It is what later reinforced the opinion of the Shafi'i Arabs in the archipelago. These Arabs initially migrated and settled in both regions of India. Pijnappel's view then gained strength from prominent Dutch orientalist figures, Christian Snouck Hurgronje (1857-1936). According to (Hurgronje, 1924, p. 7) in several port cities of the Indian Continent, Islam emerged and gained a place from traders in the Middle East trade with the Archipelago. These people then came to the archipelago to start the religion of Islam. They were followed by Arabs who helped resolve the spread of Islam they had begun. This opinion subsequently received approval from J.P. Moquette concluded that the place of origin of Islam in the archipelago was Gujarat (Moquette, 1912, pp. 536-548). This conclusion came after Moquette formed a tombstone in $\mathrm{Pa}$ sai, precisely dated 17 Zulhijjah 831/27 September 1428. This tombstone is the same shape as the tombstone found in Cambay, Gujarat. It then led to the conclusion that the people from there also brought Islam to the archipelago.

The second opinion is the opinion that links Islam with the Coromandel and Malabar. This second opinion emerged from several leading scientists, among them was the Witness. Arnold and G. E. Morisson. According to Arnold, Islam was brought to the archipelago from the Coromandel and Malabar. It is based on the similarity of the schools of jurisprudence between the two regions. Besides, according to Arnold, traders from Coromandel and Malabar had a role in trade between India and the archipelago. They not only became involved in business but also participated in spreading Islam (Arnold, 1913, pp. 364-365). Arnold's opinion then got a fresh breeze when $G$. E. Morisson opposed the Moquette tombstone theory, which automatically weakened the Gujarat theory. According to Morisson, during the Islamization of the Pasai Ocean, whose first king died in 698 AH/1297 AD, Gujarat was still a Hindu kingdom. Based on these conclusions, Morisson concluded that Islam in the archipelago did not originate from Gujarat but from the Coromandel Coast at the end of the XIII century (Morrison, 1951, pp. 31-37).

The third opinion is the theory which states that Islam was brought from the Arabian Peninsula. One of the scientists who support this theory is W. Arnold, which according to him, was Coromandel and Malabar, was not the only place of origin for Islam, but Islam also came from the Arabian Peninsula. According to him, Arab traders were one of the dominant traders in West-East trade since the early centuries of the Hijri or VII and VIII centuries $\mathrm{AD}$, which also helped spread Islam. This opinion is then supported by facts found in Chinese sources (New History of the Tang Dynasty (608-908), which states that in $674 \mathrm{AD}$, an Arab merchant became the leader of an Arab Muslim settlement on the coast of Sumatra. Some of these Arabs do marriages with local women and form a Muslim community. According to Arnold, it was the members of the Muslim community who later participated in spreading Islam (Arnold, 1913, pp. 364-365).

Arnold's opinion above received reinforcement from Niemann and de Hol- 
lander, who stated that Islam came from Hadramaut (Yemen) (Drewes, 1968, p. 439). Besides these two academics, this theory received support from Syed $\mathrm{Mu}$ hammad Naquib al-Attas. He stressed the importance of looking at the history of Malay-Archipelago Islamic literature and the history of the Malay world view to find out where and when Islam came to the archipelago, as seen in the changes in key concepts and terms in MalayNusantara literature in the X-XI / XVIcentury. XVII (al-Attas, 1969, p. 1). According to Al-Attas, before the seventeenth century, all Islamic religious literature did not record one Indian Muslim author or work originating from India, mostly from Arabic or Persian, both ethnic or cultural groups (Azra \& Burhanudin, 2012, p. 13). This Arabic theory then received approval from various scientists in Indonesia. It can be seen from the results of the seminar on the arrival of Islam in Indonesia in 1969 and 1978 which concluded that Islam came from the Arabian Peninsula, not from India, not in the XII century or XIII but the first century Hijri or VII century AD (Hasjmi, 1989, p. 7).

The next problem that arose after the agreement on the origin, time, and place of arrival of Islam in the archipelago was how then with Islamization in Java generally and in Indramayu in particular. An issue related to the focus of this research. Some scientists in Indonesia concluded that among the spreaders of Islam on Java was Maulana Malik Ibrahim. According to reports, he Islamized in many areas on the north coast of Java, even trying several times to persuade Raja Majapahit, Wikramawardhana (13861429 AD), to convert to Islam (Winstedt, 1917 , p. 175). However, who had an essential role in Islamization in the land of Java was Raden Rahmat, a son of an Arab cleric in Campa, who was later seen as the leader of the Wali Songo with the title Sunan Ampel. In Ampel he founded a center for Islamic science. During the fall of Majapahit, Islamization continued to Sheikh Nuruddin Ibrahim bin Maulana
Izrail, better known as Sunan Gunung Djati. He is based in the Sultanate of Cirebon (Winstedt, 1917, p. 175). Islamization in Cirebon has a vital position in opening up information about Islamization in Indramayu because Cirebon is the center of the spread of Islam in West Java. Besides, a study of Indramayu's past will find its context "more intact" when it is associated with Cirebon. That Cirebon as a political center appeared since the 17th century when the VOC still had a significant influence on the kingdoms in the archipelago (Study Pudjiastuti on Sultan Kanoman's Letter, see "Kodikological Study of Sultan Kanoman, Cirebon (COD. OR. 2241 ILLB 17 Number of 80) (Pudjiastuti, 2007, pp. 51-61). When and how Islamization in Cirebon will provide more or less information about when and how Islamization in Indramayu.

Several studies have been carried out that specifically talk about the history of Indramayu or history of Islam in Indramayu, includingSejarah Indramayu by Dasuki (Dasuki, 1977). The book talks about the origin of the name Indramayu, the Indramayu region during the Sunda Kingdom, and tells a little about Indramayu during the reign of Cirebon. Menapak Sejarah Indramayu by Supali Kasim (Kasim, 2011). The book consisting of eleven chapters, talks about the history of Indramayu with a thematic approach. The history of Indramayu is explained quite comprehensively, but the entry and development of Islam are discussed in a limited section in the section of Pengaruh Kesultanan Cirebon. Sejarah Masuknya Habaib ke Indramayu (Afif, 2018) by Afif Shaleh. This article explained about the religious condition of the Indramayu people when Islam came and the beginning of the arrival of the habaib community in Indramayu. This article talks more about the habaib community in Nusantara and Indramayu without mentioning how they spread the religion of Islam and 4) Mencari Jejak Wiralodra di Indramayu (Nurlelasari, 2017) by Dini Nurlelasari. This article talks more about the process of forming Indramayu into a district-level central gov- 
ernment. This article does not discuss at all about the entry of Islam and its development in Indramayu. Based on studies of the history of Indramayu and Islam in Indramayu, there has been no research that talks about the process of Islamization in Indramayu. Therefore, this research was conducted to fill the knowledge gap about the Islamization process in Indramayu.

\section{RESEARCH METHOD}

This study uses the historical method. This method is divided into four steps: (1) Heuristic; according to Renier, heuristic was taken from the Greek, Heurisken, which refers to get (Renier, 1997). Getting in literally is an effort of searching, finding, and collecting the historical resources. Managing the sources in this research is done in two ways: written sources and artifact source or field research. The written sources about the Islamization process in Indramayu can be found in archives, books, and articles; Sejarah Indramayu by Dasuki (Dasuki, 1977), Menapak Sejarah Indramayu by Supali Kasim (Kasim, 2011), Sejarah Masuknya Habaib ke Indramayu (Afif, 2018), Mencari Jejak Wiralodra di Indramayu (Nurlelasari, 2017), and Babad Cirebon (Rochani, 2008). The artifact source or field research can be found in several locations; the Arab Village in Sindang, Indramayu, and the propagator's graveyards in several places.

(2) Criticism. According to Nina Herlina (Herlina, 2011), criticism is a step or activity to research the source, information, historical tracks critically. Criticism included external and internal criticism. According to Garaghan, six questions must be answered in doing this step: time, location, author, analysis, integrality, and credibility (Garaghan, 1946). The source that is criticized can be said as a historical source if corroboration has done in this step. Corroboration is the supports of data with the other source, which has no importance relation (Herlina, 2011). In this research, the written source will be corroborated with the result of tracking the artifact source, which is found in the field. (3) Interpretation. Interpretation is interpreting historical facts. To avoid subjectivity, interpreting is done by standing to the facts and sources which have already found. This step is divided into two things; analysis and synthesis. An analysis is explaining then synthesis is uniting. (4) Historiography. Historiography is writing the result of the research by considering the selection, imagination, and chronology (Herlina, 2011).

The historical method then collaborated with Islamic social movement theory. Islamic social movement or Islamic activism, according to Wiktorowicz (Wiktorowicz, 2012) is a variety of feuds/ movements that often arise in the name of Islam. It including propaganda movements, terrorist groups, collective actions are originating from Islamic symbols and identities, political movements that seek to establish an Islamic State, and groups which are oriented in carrying Islamic spirituality through collective efforts. The main concern in the Islamic social movement is how ideas are socially created, organized, and disseminated. The emphasis in the Islamic social movement is on the process of developing discourse and ideational packages produced. In this case, a movement must frame (framing) its arguments to get support and community participation (Kurzman, 1994). The framing process will be used as one focus to analyze the Islamization process in Indramayu.

\section{RESULTS AND DISCUSSION}

Three big things will be discussed about the entry and development of Islam in Indramayu; first, regarding the place where Islam first entered Indramayu. Second, regarding the initial year of the entry of Islam in Indramayu. Thirdly, concerning figures or communities or groups who had a major role and influence in the process of Islamization in this region from the beginning of the entry of Islam to the 19th century.

Regarding the first place of entry of Islam in Indramayu, it can be seen from the generality that took place in the archipelago with regard to the first place of the 
Islamization process. According to $\mathrm{A}$. $\mathrm{H}$. Johns quoted by Azyumardi Azra, the process of Islamization in the archipelago originated from port cities, such as the Pasai Ocean, Malacca, and cities located on the north coast of Java (Azra, 1989, p. xiii). It then led to the initial conclusion that Islam first entered Indramayu through Cimanuk Port, a talented and large trading port in the Indramayu region. The statement of Denys Lombard also supported it. He stated three stages in Islamic infiltration in the North Coast region of Java. Firstly, it cannot be denied that the Islamization of the North Coast region took place through a trading port since the 15 th century $\mathrm{AD}$, and the traders played a significant role. Secondly, the inclusion of Islam in the interior gradually led to the bourgeoisie (ulama) of Islam in the interior. Thirdly, the formation of "rural Islamic networks" by pesantren and tarekat (Huda, 2007).

From the information above, it can be seen that in addition to entering through a trading port, Islam in the North Coast region of Java also entered through Islamic networks in rural and inland areas. It then led to the process of Islamization in the important role of an area which became the center of the spread of Islam in West Java, Cirebon. Talking about the entry of Islam into Indramayu cannot be separated from the important role of Cirebon. Cirebon occupied an important position in the discussion of the entry and development of Islam in Indramayu because besides, Cirebon was the center of the spread of Islam in West Java, Indramayu itself at the beginning of the development of Islam was the territory of Sunda and Cirebon. Islam did not experience significant progress when the Kingdom of Sunda ruled the Indramayu area because, according to Ricklefs (Ricklefs, 2010, p. 11), the Sundanese kingdom did not permit Muslims to enter their territory, even if only in a limited amount. It was confirmed by the statement of Cortesao (Cortesao, 2015, p. 242), who stated that the Sundanese Kingdom was afraid that Muslims would act as devious as they did in Java. Muslims do not have power, but for people in the Sunda Kingdom, they are cunning people, and with cunning, they will make them rulers of existing kingdoms.

According to the script Carita Purwaka Caruban Nagari, Islam entered Cirebon around the 14th century $\mathrm{AD}$. As time went on, Islam spread to the surrounding area (Adeng et al., 1998, p. 29; Lubis, 2014, pp. 69-70; Zuhdi, 1996, p. 203). It is a little different from the statement of Tome Pires, a Portuguese writer who visited Cirebon around 1513, according to the Cirebon region, when his arrival was under the authority of the Demak Sultanate. The ruler is Lebe Usa, as Pate Rodin's subordinate. Tome Pires said that Islam was present in Cirebon forty years before his arrival (Pires, 1967). The calculation of the year of the presence of Islam in Cirebon based on the news of Tome Pires was between 1470-1475.

Islam entered Indramayu based on the above information; conclusions can be drawn in the 15 th century. It can be seen from the footsteps of a scholar named Syeh Datuk Kahf. Its existence began when in 1420, he arrived in Cirebon and settled in Pesambangan, Giri Amparan Jati. Ki Gedéng Tapa then permitted the cleric, Singapore's state ruler (one of the small kingdoms in Cirebon, at that time) to establish Islamic boarding schools in Kampung Pasambangan, Giri Amparan Jati. At the time of occupying the Amhaan Jati region, the significant influence of the Syeh Datuk Kahf/Syeh Idhofi/Syeh Nurjati (brother-in-law of Sultan Sulaiman from Baghdad) reached the Indramayu region. It can be seen from the petilasan in Pabean Ilir Village (Pasekan District). Petilasan is in the form of a grave believed to be the grave of Sheikh Datuk Kahf. Archeologically the Sheikh's cemetery Datuk Kahf at Pabean Ilir cannot be included in the grave category in general. Only a place that is believed that Syeh Datuk Kahf had visited and spread Islam there.

Historically the role of Syeh Datuk Kahf in the spread of Islam in Indramayu since the 15th century correlated with the intensive development of Islam in other 
Javanese regions which began in the 15 th century. It is supported by the fact that in the previous century ( 7 th to 14 th century), people in Java were under the influence of Hinduism (Kasim, 2011, p. 178). The relay of the spread of Islam in Indramayu then continued to the sons and daughters of King Siliwangi.

King Siliwangi's descendants also played a role in Islamization. It began when Syeh Datuk Kahfi became a teacher of Prince Walangsungsang, Nyi Mas Rarasantang, and Pangeran Kian Santang. They are the children of King Siliwangi (Raden Pamanah Rasa) and Nyi Mas Subanglarang. Prince Walangsungsang is known to have several aliases: Mbah Kuwu Sangkan, Pangeran Cakrabumi, Cakrabuana, Ki Somadullah, and Abdullah Iman. Meanwhile, Nyi Mas Rarasantang is the mother of Syarif Hidayatullah or Sunan Gunung Jati. Then, Prince Kian Santang was known as Raja Sengara.

Role of Prince Walangsungsang or Mbah Kuwu Sangkan in the spread of Islam in West Java in the late 15th and early 16th centuries, including in Indramayu can be seen from historical and archaeological evidence. Archaeological evidence manifests itself from the 60 graves of $\mathrm{Ki}$ Gede from villages in Indramayu, which are in the Astana Gunungjati Cirebon cemetery, where Prince Walangsungsang is located. It proves the influence of the character has penetrated the regions of Indramayu. The Islamization method chosen by Mbah Kuwu Sangkan is a lot through cultural media, especially art, such as Rudat Dance, Berokan, Cepak/ Menak Wayang Puppet, Purwa Leather Puppet, Mask Dance.

The Walangsungsang period was the beginning of the spread of Islam intensively to the Cirebon and Indramayu regions, in $1445 \mathrm{AD}$, which year was also the first year of the formation of the Cirebon region with the opening of the Caruban or Cirebon villages or called Lemah Wungkuk (Adeng et al., 1998). The period continued until $1452 \mathrm{AD}$ when Prince Walangsungsang founded the Pakungwati Palace, which functioned as his grand pal- ace (Rochani, 2008: 95). Later in the 1500 s, Islam began to gain legitimacy, which can be seen from the establishment of an Islamic-style kingdom. A kingdom that makes Islam its official religion.

After gaining legitimacy, the spread of Islam became increasingly widespread. It can be seen in Walisanga's time. The Islamization at this time has gone far into the West Indramayu area, such as Kandanghaur, Lelea, and Haurgeulis, which is contributed by Prince Sentana Panjunan and Pangeran Wira Panjunan, two grandchildren of Sunan Gunung Jati (Dahuri, Irianto, \& Nur Arovah, 2004, p. 62). Besides, during this Walisanga period, the influence of Islam had entered the system of government. It can be seen from the Death Administration in Indramayu, which has adopted the pattern of the Islamic city. The center of his government is characterized by among others (a) south of the square is pendopo, (b) west of the square is the mosque, (c) east of the square is the prison, and (d) north of the square is very likely beforehand is a market (Munandar, 2007, p. 14).

Searching for sources related to the spread of Islam in the Indramayu region can be seen from the role of the disseminating figures, it can also be revealed through the information that appears from a famous river name in the area, namely Cimanuk. The mention of the name Cimanuk in the spread of Islam in Java in general and in the territory of Cirebon, in particular, will refer to a figure named Raden Kusen, sister of Raden Patah. Another name for this character, according to the manuscript of the State of Kertabhumi and Mertasinga Babad is Kin San or Dipati Terung or Adipati Terung. His name became known since he killed Sunan Ngundung, Sunan Kudus's father, in a conflict in Demak. Although Sunan Kudus did not claim revenge for the death of his father, Raden Kusen still felt guilty. In response to these feelings of guilt, he chose to explore religion elsewhere. The place is around the lower reaches of Cimanuk, which includes the Cirebon area (Kasim, 2011, p. 176). 
The presence of these figures is reinforced by an oral tradition that links it with Indramayu. The story was obtained from Raffan S. Hasyim (2007), which according to him, the story flowed from generation to generation from his greatgrandmother Asmawi Wasitaharja to his grandfather Muh. Herman, then to his father Muh. Hasyim and finally to himself. The story tells about the existence of Dipati Tarung or Duke of Eggplant (Raden Kusen/Kin San). Adipati Terung is the son of Arya Damar (Arya Abdillah), Duke of Palembang, who is also the son of Bre Kertabumi (Brawijaya VI). Dipati Terung, the younger brother of Raden Patah (Panembahan Jin Bun), after entering Islam, still feels guilty about Sunan Kudus. It because he was involved in the beating, which resulted in the death of Sunan Ngundung, Senopati Kingdom of Demak (Sunan Kudus father) even though Sunan Kudus will not sue his father's death. Therefore, Dipati Tarung left for Cirebon to study with Sunan Drajat, who at that time was helping Sunan Gunung Jati preach in Cirebon. After feeling enough, Dipati Terung also asked permission to participate in spreading Islam. With the consent of Sunan Gunung Jati, Dipati Tarung then chose an area located in Indramayu now. The story then revolves when Dipati Tarung from Banyu Biru is married to residents around the Cimanuk River (no name). The results of the marriage then gave birth to the genealogy of descendants as follows: Dipati Tarung - Ki Gede Baludan Banjaran Sari (Penganjang) - Menjangan Abang. Menjangan Abang lowers (1) Ki Gedig, (2) Ki Lodak, (3) Nyi Surada. Ki Gedig took down Ki Masrab. Ki Masrab decreases (1) Mukibah, (2) Sabiah, (3) Sawinah, (4) Salami, and (5) Sawini. Mukibah lowered; (1) Arkamah, (2) Madkasan, (3). Djujinah, (4) Moh. Asmawi Wasitaharja, (6) Mursinah, (7) Mursinih. Sawinah lowered; Achmad - Muh. Herman -Muh. Hasyim - Raffan S. Hasyim. From the above pedigree, it can be seen that $\mathrm{Ki}$ Lodak (Penganjang) married Nyi Gede Paoman and then was born Menjangan
Abang, who later became known as $\mathrm{Ki}$ Gede Paoman (Kasim, 2011, pp. 177178).

Also, in this 16th century, other figures influenced the development of Islam in Indramayu, namely Shaykh Semaun or Mbah Semangun. He is from Aceh, another opinion from Arabic. At first, he wanted to spread Islam in Gresik, East Java, but due to the many scholars and residents there who embraced Islam, eventually, the journey continued to the west. The boat he was riding stopped Dadap Indramayu Village. Then he set up a simple little hut around the beach. He has a child. His name is Kiai Syakir, lives in Indramayu's Wotgalih. The spread of Islam began to be massive just by his son, around the 16th century. However, this source requires a more in-depth study, because as long as this written record has not yet been found, it only develops in an oral tradition. No traditional historiography or colonial archives mention their names.

Entering the 17th century, the development of Islam in Indramayu was more colorful with the arrival of residents from Mataram. It can be seen from the book History of Indramayu (Dasuki, 1977, p. 154), which is written that in 1630 Sultan Agung transmigrated residents from Mataram and the surrounding areas to settle in Karawang, Ukur (Bandung), Sumedang, Ciasem, Cilamaya, and others. They were ordered to open up agricultural land, which would be a place for supplies of soldiers to attack Batavia. Mataram then multiplied transmigrants to Indramayu with the same purpose in 1641. Indramayu also began to have many rice fields. When Mataram controlled most of Java, the name Indramayu was mentioned in various sources as the location of local transmigrants from Java based on the policy of the king of Mataram, Sultan Agung. It is supported by information that appears in the book Kingdom of Cerbon 14791809 (Sunardjo, 1983, pp. 117-120). In the book, it was written that to expel the VOC, Sultan Agung (Mataram) launched an attack on Jayakarta in 1628 with the strength of almost 10,000 people taken 
from various subordinate areas on the north coast, from Demak to Tegal which was assisted by the Cirebon and Banten warriors.

Although the attack failed, but did not dampen Sultan Agung's intention to control Jayakarta. It can be seen from the emergence of the second attack in 1629, which was also with a large force after obtaining additions from Priangan and Bandung (Measuring) even though they eventually suffered defeat because of the elements of logistics and coordination. After the loss, Sultan Agung then made a new strategy on the north coast of West Java. Many residents from Central Java, both farmers and war veterans were forced to move to the northern coast of West Java until 1632, like local transmigration. They occupy Bekasi, Karawang, Subang, and Indramayu areas. The estimation of Sultan Agung drove this after seeing the VOC base its navy on the northern coast of Central Java and East Java. The Mataram king predicted that the VOC would turn around to destroy Mataram's rule in Java. The existence of Indramayu in the Mataram era can also be seen from Dutch letters. Some of the letters show the presence of the Banten Sultanate movement to the area now called Indramayu. Banten and Mataram at that time were indeed fighting over influence in western Java, after the collapse of the Sunda-Pajajaran Hindu kingdom and the development of Islam in Java (Kasim, 2011, pp. 180-182).

Entering the 18th century or the last century of VOC rule, Islam in Indramayu then began to develop along with the emergence of congregations. Some tarekat started to appear around the end of the 18 th century until the beginning of the 19th century. Its existence then led to the spread of Islam in Indramayu, reaching its highest point. It can be seen from the emergence of writing or copying the books of Islamic religion, the books of remembrance, and the books of Tawheed. The books were produced in the palace and later plagued and believed the people of Indramayu. In Indramayu, the teachings of the tarekat emerged at the end of the 18th century. Its development was earlier than the development of the instructions of the Shari'ah worship. It can be seen from the emergence of tarekat texts which are larger than the fiqh texts. Jurisprudence, as far as there is only one, it contains a paper stamp in the form of a person using a shovel and next to it is a horse, and a comparative stamp in the form of Behr \& Singapore (Christomy \& Nurhata, 2013). Referring to the book Watermarks in Paper (Churchill, 1967), the estimated time for making and writing is the 19th century. The tarekat is one of the answers to the third question about the Islamization of Indramayu. It is because in the tarekat there are influential figures and communities in Islamization. This role began from the beginning until the 19th century. In this period arose the Arab community began to determine their position.

\section{The Tarekat Community in Indramayu in the 18th Century}

Indramayu community has its way of defining the term tarekat. For them, the tarekat is the law. Pullat is Kiratabasa, which means it is pulled and tied. In this context, it is drawn from the behavior of the Shari'a to the practice of the tarekat. If you are already in the circle of the tarekat, so that it does not come out again, it must be tied. The culprit is called Sufi; his behavior is called tirakat. Tirakat is often equated with private practice carried out by ordinary people, such as fasting, reducing sleep hours, and avoiding worldly pleasures. Tirakat then becomes its definition, separate from the definition of tarekat in the real sense. In KBBI, tarekat is the path to the truth (in Sufism). The tirakat is defined as holding back the passions (such as fasting, abstaining). Tirakat can also be interpreted as seclusion into a quiet place (on a mountain and so on).

In Indramayu, tarekat teachings are expected to emerge at the end of the 18th century. Its development was earlier compared to the practice of shari'a worship. Manuscripts containing tarekat instructions are more significant than the fiqh 
texts. The fiqh script, as short as this one, found only one, includes a paper stamp in the form of a picture of a person using a spade and next to it is a horse and a comparative stamp in the form of Behr \& Singapore. Referring to the book Watermarks in Paper (Churchill, 1967), the estimated time for making and writing is the 19th century.

In Indramayu, the texts which contain tarekat teachings, are usually called lontar petarekan. The term lontar refers to the ancient manuscript, while petarekan relates to the teachings of Sufism and Tawheed. For researchers who happen to face a text entitled Petarekan, which is usually written on the front cover, then there are two possibilities: containing the teachings of monotheism and the teachings of the tarekat. Searching for Islamic history, or culture in general, clearly requires a script, if the research does not want to be regarded as mere guesswork.

A text entitled Petarekan contains seven kinds of tarekat remembrance, combined into one, namely Qadiriyah, Naqsabandiyah, Istiyah, Anfasiah, Syatariyah, Jaediyah, and Muhammadiyah. The scriptwriter gives the title. Inside it is equipped with salawat readings. This text has no dating information, but contains the Eendraght Maakt Maght paper stamp, as a guide for estimating the writing time. If you see a list of images in the Watermarks in Paper, the estimated time for using European paper as the writing pad is 1667-1800 (Churchill, 1967, p. 28).

Besides, the context of the text can also help with the process of identifying estimates. The mention of the name of the Muhammadiyah Congregation, another name for the Muhammadiyah Order, as the youngest congregation among the seven tarekat, is estimated to be the time of writing and its spread around the 18th century. Terekat founded by Muhammad ibn Abdul Karim al-Madani al-Syafii alSamman (1718-1775) this had a massive number of followers in the archipelago, which was underlined by his students at the end of the 18th century.
In Cirebon and Indramayu, the tarekat began to institutionalize, complete with a set of rules as understood, the first to appear was Syattariyah. Its founder Sheikh Abdullah Asy-Syattari (d.1485 M), a cleric who had relations with Umar Suhrawardi (1145-1234 M) (Mulyati, 2005: 26). The distribution to the land of Cirebon was carried by Syekh Haji Abdul al-Muhyi, Syekh Abdu ar-Rauf Singkel's student, Aceh. From Shaykh Haji alMuhyi then to Kyai Pangulu or Kyai Talabudin (Batang), then to Kyai Muqayim (Sapatan Village, Cirebon). Next to Kyai Mas Arifin (Ngatuk Village), then to K.H. Syarqawi (Babakan Village, Ciwaringin, Cirebon (formerly entered Majalengka area), and finally to Kyai Bulqih (Sidapurna Village), but here, the distribution center is not based in Indramayu.

About genealogies described in the Tarekat Syattariyah manuscript belongs to Rafan Hasyim collection. In the first part of the Syattariyah tarekat there is a snippet as a "reminder", Man arafa nafsahu waqad "arafa rabbahu" for those who know him means he knows his God" That is the basis before arriving at the issue of Shari'a. Here below is the pedigree:

\section{Syattariyah Lineage in Cirebon Kanjeng Rasulullah}

Sayidina Ali bin Abi Talib Radiyallahu 'Anhu Sayid Husain asy-Syahid Sayidina Zainal Abidin Imam Muhammad Baqir Imam Ja'far Sadiq

Rahani Sultan Arifin Abi Yazid al-Bustami Syekh Muhammad Magrib

Qutub Abu Mudfari Maulana Rumi Tuse Qutub Abi Hasan al-Harqani

Syekh Huda Aqli Mawara an-Nahari Sayid Muhammad Asiq Syekh Abdullah Asy-Syatari Hidayat Sarsani Syekh Haji Husuri

Syekh Sayid Muhammad Gaus bin Sayid Hatirudin

Sayid Wajhudin, Uluwiri genus Sigatullah bin Sayid Rahullah Sayyidina Abi Mawahib Abdullah Ahmad bin Ali, Abas genus, from Syanawi country Syekh Ahmad bin Muhammad, from Madi- 


\author{
nah country. \\ Syekh Abdu ar-Rauf bin Ali, Fansur genus, \\ from Singkil region \\ Syekh Haji al-Muhyi, from Karang country, \\ Saferwadi village \\ Kyai Pangulu Kyai Talabudin from Batang \\ region \\ Kyai Muqayim from Syarbon region, \\ Sampiran village \\ Kyai Mas Arifin from Syarbon region, \\ Ngatuk village \\ Kyai Haji Syarqawi from Majalengka region, \\ Babakan village \\ Kyai Bulqih from Syarbon region, Sidapurna \\ village
}

From lineage above, it appears that there are no mursyids from or living in Indramayu, all of them from Cirebon. Even so, it was strongly suspected that his students were mostly from Indramayu, especially in the west. One of the factors that pushed this tarekat became large was because it gained legitimacy from the Babad Cirebon text. In the text narrated, Sunan Gunung Jati appealed to the community to join the Syatariyah Order. Many of the courtiers joined this tarekat, then followed by the surrounding community. The name Sunan Gunung Jati itself, from several Syattariyah texts found in Cirebon and Indramayu, is not included in the list.

There are three Syattariyah tarekat texts found in Indramayu. First, the text of the Ki Tarka collection, written on European paper, is thought to have been written in the 19th century. Second, the manuscript collection of Kiai Syamsuddin, written on Daluwang paper, is estimated to be written in the 18th century. Third, the manuscript of the Ki Sonda family collection, written on striped paper by Ki Sonda in 1963. The last manuscript is sourced from a manuscript written in 1890. The three texts do not contain the lineage of the tarekat.

In addition to the Syattariyah congregation, two more groups developed in Indramayu, namely Qadiriyah and Qadiriyah Wanaqsabandiyah. Qadiriyah in Indramayu is only a kind of "pengajian community". There, the people only read tawasul and read the book manaqib or Bi- ography of Sheikh Abdul Qadir Jilani. Four Qadiriyah manuscripts from Indramayu are all alone in the form of manaqib. As short as this has not been found, the manuscript of the Qadiriyah Order which is accompanied by genealogies, ordinances for disbanding, conditions of joining, and so on.

Meanwhile, the Qadiriyah Wanaqsabandiyah Order, its teachings are more complete, and the lineage is brighter. Among other congregations, this congregation entered and developed in Indramayu more recently, but the number of followers was very large, especially among poor people. The three distribution points are in Cikedung Lor (Sheikh Abdullah), Munjul (Sheikh Abdul Gofar), and Paoman (Sheikh Abdul Manan). Distribution to Indramayu through Syekh Talhah Kalisapu Cirebon.

Until the tarekat teachings were widespread, one of the factors was the role of the copyist. The copyist or writer needs to turn his brain, thinking about how the tarekat teachings become grounded. The tarekat instructions, at least according to their subjectivity, are considered relevant for the context of society, such as Indramayu. Two Petarekan manuscripts and two Syattariyah congregation texts, as listed above, are written in Javanese script or Carakan, Javanese. In his time all text, only understood in Javanese language and writing. Perhaps the message or teaching contained in the text does not reach the reader if he continues to use Arabic and Arabic script. That is excellent ijtihad carried out by our ancestors, which significantly influences the people around them, to form a distinctive pattern: Islamic Indramayu.

\section{Arab Community}

Entering the 19th century or the entry of the Dutch East Indies government, Islam in Indramayu grew as the Arabs settled and formed colonies/communities. The role of the Arabs is vital. According to van den Berg, they are navigators and traders who have introduced Islam in the archipelago. Starting from Aceh, then Palem- 
bang, and in the eighteenth century on the island of Java(van den Berg, 1989, p. 67). Many Arabs live in cities that have been part of the trade routes in Southeast Asia since the time of the commercial period. However, the number of Arabs who settled (not only seasonal migration to trade and then returned) was only significant in the 19th century when there was a transfer of power from the VOC to the Dutch East Indies government. The Arabs played an essential role in the development and control of intra-island shipping in the early years of the establishment of the colonial state (Mandal, 1994, p. 1).

These Arabs began to settle a lot on Java after 1820 and in Cirebon and Indramayu in the 1840s. It can be seen from the census of the Dutch East Indies government in 1859. In that year, the number of the Arab population in the Cirebon colonies (Cirebon, Indramayu, and Jatiwangi) amounted to 533 people. This number increased in the 1870 census, with a total of 816 people. In the census of 1885, the number of Arabs in Indramayu reached 374. In Cirebon, there were 834, and in Jatiwangi there were two. The total number of Arabs in the Cirebon colony in 1885 totaled 1210 (van den Berg, 1989, p. 67).

The history of the existence of Arabs in Indramayu can be referred to as the existence of Arabs in Cirebon. In 1845 when the number of Arab colonies in Cirebon was large enough to require ahead of a settlement which eventually became the head of all Arabs at the Residency. In 1872 Arab settlements in Indramayu then chose to separate themselves and have their colonies. The head of the group in the Arab colony is called Abu. The characteristics of the Arab colonies in Indramayu are the same as the Arab colonies in Cirebon. Most live from trade with natives. Being the head of the settlement for the Arabs is not a proud thing as well as wealth, let alone honorary titles such as lieutenant, major, or captain. The position of the head of the colony was not a position which gave rise to interest from the Arabs.
The Arabs obeyed the head of the colony if the law required it, and those who did not follow would be punished as rebels. The head of the settlement, who before his appointment was not an influential person, would find it difficult to exert influence on the people in his colonies. Ahead of a colony, that is not of a noble class will not be considered by the people in his colony, like a sayyid (descendant of the Prophet Muhammad), who indeed will not obey a badui. Seeing these conditions, the Arab communities formed will be in tune with the similarity of degrees, status, or influence of each person. This then encouraged the importance of knowing the characteristics of Arab immigrants who came to the archipelago. It aims to find out their role in the spread of Islam, especially in the Indramayu region.

Arab communities in Cirebon and Indramayu have several characteristics. These characteristics are as follows. (1) The Arabs who decided to move were not the wealthiest group in Hadramaut. (2) No Arab had arrived in Batavia just to spread religion. There was a motive for the trade brought. (3) The Arabs when deciding to trade will prefer to employ a young person from his family or tribe; (4) It is rare for an Arab to arrive in the archipelago without knowing someone who will accept it with open arms, especially if he is a sayyid; (5) An Arab who comes from Hadramaut to the Archipelago, even without the protection of the rich, can obtain wealth quickly enough if seen from their income in their own homeland and they can quickly adjust to the lives of indigenous people; (6) Saving is their culture, and when they get rich they never forget their relatives in their homeland. If there is still more money, it will contribute to mosques, schools, or religious foundations; (7) The spirit of prosperity has been institutionalized in the Arabs. This can be seen from their adherence to the principles of Islamic law regarding zakat; (8) No Arabic Hadramaut is addicted to liquor or opium; (9) Any Arab as miserable as possible can guard his daughter against prostitution; (10) Arabs value civilization and 
science; theology, jurisprudence, and especially in grammar; (11) Among the various causes of the disunity of the Arabs was the antipathy of Arabs born in Hadramaut against mixed Arabs, or the antipathy of poor sayyids towards wealthy merchants from lower classes; (12) Arabs never send their children to public schools or to mission schools; (13) Most Arab homes are dirty and not at all attractive to European guests; so did the interior of their house that was not arranged like European tastes; (14) Wives and daughters will spend more time at home; (15) Arabs are used to talking arbitrarily and lacking respect for the government; (16) The characteristics of other Arabs were opposing, litigant, and their incessant contention with native priests regarding Islam; (17) The Arabs did not tolerate a sense of income, were not friendly in trading, and many were stingy (van den Berg, 1989); (18) Arabs are aware that to have a brilliant career in the Indies must change their name to Java, for example, Kiai Mas.

Based on the characteristics of the Arab immigrants above, it can be seen that some of the characteristics that make the spread of Islam in Indramayu experience a relatively rapid development when they come and settle. These characteristics are generous attitudes toward things that are religious and have a love of science. Culture in society will shape and influence actions and thought patterns in society, both ethnic and religious identity. Habit or habitus in culture contributes to personality, in this case, the Islamic character. To build an Islamic personality, we must realize the application of the environment through culture and the implementation of traditions that instill Islamic values so that the culture of a society can practice Islamic teachings in the social order, that is, culture (Suratman \& Kurniawan, 2019, p. 68).

There are Arab figures who played an important role in the Islamization of Cirebon and Indramayu. He was Sayyid Abdur Rahman bin Muhammad BasySyaiban who had come from Hadramaut to Cirebon in the early 18th century. He married one of the Sultan's daughters. His two sons were named Sulaiman and Abdur Rahim. One of Abdur Rahim's sons named Said, his tomb is located in Krapyak. His three sons are named; Hasyim (Raden Wongsorejo), Abdullah, and Alwi (becoming Regent of Magelang with the title Raden Tumenggung Danuningrat I in 1813) (van den Berg, 1989).

\section{CONCLUSION}

This study seeks to answer three big questions about Islamization in Indramayu. Firstly, the place where Islam first entered Indramayu. Secondly, regarding the initial year of the entry of Islam in Indramayu. Thirdly, concerning figures or communities or groups who had a significant role and influence in the process of Islamization in this region from the beginning of the entry of Islam to the 19th century. The first place for the admission of Islam in Indramayu was through the Port of Cimanuk. Besides, Islam in Indramayu also entered through Islamic networks in rural and inland areas. The early year of the entry of Islam in Indramayu was in the 15 th century. It can be seen from the footsteps of a scholar named Syeh Datuk Kahf. Its existence began when in 1420 , he arrived in Cirebon and settled in Pesambangan, Giri Amparan Jati. The presence of the tarekat and the Arab community became the backbone of the Islamization in Indramayu. The first congregation in the Cirebon Residency was the Syattariyah Order. The spread of this tarekat began with Sheikh Haji Abdul alMuhyi, Syekh Abdu ar-Rauf Singkel's student, Aceh. From Shaykh Haji al-Muhyi then to Kyai Pangulu or Kyai Talabudin (Batang), then to Kyai Muqayim (Sapatan Village, Cirebon). Next to Kyai Mas Arifin (Ngatuk Village), then to K.H. Syarqawi (Babakan Village, Ciwaringin, Cirebon (formerly entered Majalengka area), and finally to Kyai Bulqih (Sidapurna Village). The Arab Community figures in the Cirebon Residency are Sayyid Abdur Rahman bin Muhammad Basy-Syaiban who came from Hadramaut to Cirebon at the beginning of the seventeenth century and 
married the daughter of one of the sultans. Two sons named Sulaiman and Abdur Rahim, one of the sons of Abdur Rahim named Said, his tomb are located in Krapyak. The three sons are named; Hasyim (Raden Wongsorejo), Abdullah, and Alwi Tumenggung Danuningrat $\mathrm{I}$ in 1813.

\section{REFERENCES}

Adeng, et al. (1998). Kota Dagang Cirebon Sebagai Bandar Jalur Sutra. Jakarta: Departemen Kebudayaan RI.

Afif, S. (2018). Seajrah Masuknya Habaib ke Indramayu. Al-Tsaqafa: Jurnal Peradaban Islam, 15(2).

al-Attas, S. M. N. (1969). Preliminary Statement on a General Theory of the Islamization of the Malay-Indonesian Archipelago. Kuala Lumpur: Dewan Bahasa dan Pustaka.

Arnold, T. W. (1913). The Preaching of Islam: A History of the Propagation of the Muslim Faith. London: Constable.

Azra, A. (1989). Perspektif Islam di Asia Tenggara. Jakarta: Obor Indonesia.

Azra, A., \& Burhanudin, J. (2012). Kedatangan dan Peradaban Islam. In Indonesia dalam Arus Sejarah. Third Edition. Jakarta: PT. Ichtiar Baru Van Hoeve.

Christomy, T., \& Nurhata. (2013). Kearifan Lokal dalam Naskah- Naskah Pesisir Indramayu: Pengembangan Budaya Pesisir Melalui Knowledge Management System. Depok: Universitas Indonesia.

Churchill, W. A. (1967). Watermarks in Paper. Amterdam: Menno Hertzberger \& Co.

Cortesao, A. (Ed.), Perkasa, A., \& Pramesti, A. (2015). Suma Oriental Karya Tome Pires: Perjalanan dari Laut Merah ke Cina dan Buku Francisco Rodrigues. Yogyakarta: Ombak.

Dahuri, R., Irianto, B., \& Nur, A. E. (2004). Budaya Bahari-Sebuah Apresiasi di Cirebon. Jakarta: Perum Percetakan Negara RI PNRI.

Dasuki, H. A. (1977). Sejarah Indramayu. Indramayu: Pemerintah Kabupaten
Daerah Tingkat II.

Drewes, G. W. J. (1968). New Light on the Coming Islam to Indonesia?. Journal of the Humanities and Social Sciences of Southeast Asia, 124(4).

Garaghan, G. J. (1946). A Guide to Historical Method. New York: Fordham University Press.

Hasjmi, A. (Eds.). (1989). Sejarah Masuk dan Berkembangnya Islam di Indonesia. Bandung: al-Ma'arif.

Herlina, N. (2011). Metode Sejarah. Bandung: Satya Historika.

Huda, N. (2007). Islam Nusantara. Yogyakarta: Ar-Ruz Media.

Hurgronje, C. S. (1924). Verspreide Geschriften (VI). Den Haag: Nijhoff.

Kasim, S. (2011). Menapak Jejak Sejarah Indramayu. Yogyakarta: Frame Publishing.

Kurzman, C. (1994). A Dynamic View Resources: Evidence From Iranian Revolution, Research In Social Movements, Conflict and Changes. London: Routledge.

Lubis, N. H., et al. (2014). Kabupaten Kuningan dari Masa ke Masa. Kuningan: Pemerintah Kabupaten Kuningan.

Mandal, S. K. (1994). Finding Their Place: A History of Arabs in Java Under Dutch Role 1800-1924. USA: Columbia University.

Moquette, J. P. (1912). De Grafstenen te Pase Grisse Vergeleken met Dergelijke Monumneten uit Hindoestan. TBG, 54 .

Morrison, G. E. (1951). The Coming of Islam to the East Indies. JMBRAS, 24(1).

Mulyati, S. (Ed.). (2005). Mengenal dan Memahami Tarekat-tarekat Muktabarah di Indonesia. Jakarta: Prenada Media.

Munandar, A. A. (2007). Sejarah Kebudayaan Indonesia: Religi Dan Falsafah. Depok: Rajawali Press.

Nurlelasari, D. (2017). Mencari Jejak Wiralodra di Indramayu. Al-Turas, $X X I I I(1)$.

Pires, T. (1967). The Suma Oriental of Tome Pires and The Book of Francisco Rodri- 
guez. Liechtenstein: Kraus Reprint Limited.

Pudjiastuti. (2007). Kajian Kodikologis atas Surat Sultan Kanoman, Cirebon (COD. OR. 2241 ILLB 17 (No. 80). Jurnal Wacana, 9(1).

Renier, G. J. (1997). Metode dan Manfaat Ilmu Sejarah. Yogyakarta: Pustaka Pelajar.

Ricklefs, M. C. (2010). Sejarah Indonesia Modern 1200-2008. Jakarta: Serambi Ilmu Semesta.

Rochani, A. H. (2008). Babad Cirebon. Cirebon: Dinas Kebudayaan dan Pariwisata Cirebon.

Sunardjo, R. H. U. (1983). Meninjau Sepintas Panggung Sejarah Pemerintahan Kerajaan Cerbon, 1479-1809. Bandung: Tarsito.
Suratman, B., \& Kurniawan, S. (2019). Tudang Sipulung in Muslim Community of Peniti Luar (Identity, Islamic Values, and Character Building). Khatulistiwa: Journal of Islamic Studies, 9(1).

van den Berg, L. W. C. (1989). Hadramaut dan Koloni Arab di Nusantara. Jakarta: INIS.

Wiktorowicz, Q. (2012). Gerakan Sosial Islam: Teori, Pendekatan dan Studi Kasus. Yogyakarta: Gading Publishing dan Paramadina.

Winstedt, R. O. (1917). The Advent of Muhammadanism in the Malay Peninsula and Archipelago. Journal of the Malaysian Branch of the Royal Asiatic Society, 77, 171-175.

Zuhdi, S. (1996). Cirebon Sebagai Bandar Jalur Sutra. Jakarta: Departemen Pendidikan dan Kebudayaan RI. 